\title{
FIGHTING MAOIST VIOLENCE WITH PROMISES: EVIDENCE FROM INDIA'S EMPLOYMENT GUARANTEE SCHEME
}

\section{GAURAV KHANNA and LAURA ZIMMERMANN}

Gaurav Khanna and Laura Zimmermann are Ph.D. candidates in Economics at the University of Michigan, Ann Arbor, MI, USA. They may be reached at gkhanna@umich.edu and lvzimmer@umich.edu, respectively.

\section{Abstract}

The Indian state faces a substantial internal security threat in the form of a Maoist insurgency, but decades of relying predominantly on military strength have not been a successful strategy for resolving the conflict. Recently, there has been a growing interest in whether anti-poverty programs can increase the effectiveness of the government forces by improving the relationship between citizens and the state and making civilians more willing to share information on insurgents. A prime candidate for such a program is the National Rural Employment Guarantee Scheme (NREGS), the world's largest public-works program. We find that the introduction of NREGS leads to an increase in violence in the short run that is driven by police-initiated attacks, and an increase in the number of captured Maoists. These results are consistent with the hypothesis that civilians assist the police because of NREGS, and suggest that the role of civilians in internal conflicts should not be ignored.

$\mathrm{L}$ ike many other developing countries, the Indian state faces a number of internal conflicts. One of the most important security threats is the Maoist movement, which aims to overthrow the government and has developed into a guerilla force that has a strong presence in many economically underdeveloped areas since its beginning in the late 1960s. In 2006, the Indian Home Ministry estimated the movement to have 15,000 members, to be active in 160 districts, and to control about one fifth of India's forests. According to a declaration by India's Prime Minister Manmohan Singh in 2006, the Maoists are the biggest threat the Indian state has ever faced. ${ }^{1}$

Confronted with such a challenge to its authority, the Indian government's preferred strategy for many years has been to rely almost exclusively on military strength, with both paramilitary forces and the police fighting Maoist cadres for territorial control. The success of this strategy in ending the conflict has been limited, however, although some Indian states have been more successful at suppressing the insurgency than others.

One potential explanation for this outcome is the role civilians play in the conflict. The Maoist insurgency is especially strong in many tribal areas that tend to be rich in natural resources but suffer from chronic underdevelopment and few employment opportunities. Since the Maoists claim to be fighting the government because of its catering to elite interests while neglecting the poor, the civilians' bad economic situation may make them more willing to support the insurgency rather than sharing information about the guerilla forces with the police. This, in turn, limits the government forces' effectiveness in tracking down rebels.

An important implication of this explanation is that the Indian government should combine its military strategy with anti-poverty programs that demonstrate its commitment to improving the economic situation of the poor and improve the relationship between the government and the people. A prime candidate for such a program is the National Rural Employment Guarantee Scheme (NREGS), which is the largest public-works program in the world and was implemented between 2006 and 2008. ${ }^{2}$

In a more technical companion paper, we analyze whether this employment guarantee program has had an impact on the intensity of Maoist violence and find that violence increases in the short run. ${ }^{3}$ While we discuss and test several potential explanations for this pattern, the most likely channel is that NREGS improves the relationship between the government and the people and thereby the flow of information that allows the police to track insurgents more efficiently.

In this article, on the other hand, we confirm the main findings of the companion paper by using a simpler empirical strategy, a difference-in-difference approach. The results show again that violence increases in the short run. In addition, we look at two other implications of the citizen-support explanation: If NREGS really induces citizens to share more information with the police, then we would expect police-initiated attacks and the number of captured insurgents 
to increase after the introduction of NREGS due to better information, and we find that this is indeed the case.

The following sections briefly describe the literature on the impact of government programs on internal conflicts and provide more detailed information on the Maoist movement and the employment guarantee program. We then discuss the data and the empirical strategy, show the results, and provide some conclusions.

Studies on the impact of government programs on internal violence

The association between underdevelopment and conflict has been a long studied relationship in the economics literature. Some studies rely on cross-country data and show a correlation between poverty and conflict, whereas other studies conduct a more micro-level analysis. Microanalyses often rely on rainfall as a determinant of income changes and show how adverse economic shocks are a strong determinant of civil wars. Therefore, the broader literature seems to show that underdevelopment is strongly associated with more conflict. There is, however, little research on the impact of development programs itself on internal conflicts. Some recent papers focus on this research question in the context of Iraq, the Philippines, and U.S. food-aid receiving developing countries. The findings are mixed, with some studies reporting positive effects and others estimating negative impacts. Various explanations for these results are advanced, including changes in the economic attractiveness of being an insurgency supporter, the rebels' attempt to appropriate the resources provided by the government program, and the increased willingness of civilians to share information with the police. This pattern could point to the nature of the conflict and the rebels' goals being important for the effectiveness of government interventions, but would also be consistent with violence-reducing impacts only setting in over time, as consistent with the results of our companion paper. ${ }^{4}$

\section{The Maoist insurgency}

The Maoists, also often referred to as Naxalites due to the beginning of the movement in the village Naxalbari in West Bengal in the late 1960s, fight the Indian government for its supposedly elitist policies that do not benefit the poor. Having started as a local uprising after landlords attacked a tribal villager, the movement had spread from West Bengal to other Indian states by the early 1970 s. A number of rivaling splinter groups continued to be active over the next couple of decades. In 2004, the two biggest groups merged to form the Communist Party of India (Maoist), which is believed to have substantially exacerbated the intensity of the conflict. Attacks
Maoist insurgents in India claim to be fighting because of government catering to elite interests. This may make the poor more willing to support insurgents rather than sharing information about guerilla forces with the police. Thus, antipoverty programs may potentially serve as a counterinsurgency strategy and lead to more police attacks and higher arrest rates of insurgents, and we find that this is indeed the case.

by the Maoists often target infrastructure projects such as telecommunication towers, but also include the killing of civilians believed to be police informers and encounters with the police and state paramilitary forces. ${ }^{5}$

The local population, often mainly consisting of tribals (adivasis), is often forced to pick sides in the conflict. The Maoists predominantly hide in remote forest areas, which make them dependent on civilians for resources and information on police force movements. They also threaten civilians to not provide similar support to the government forces. Some experts also point to the often excessively brutal way civilians are treated by the police, however, which undermines their trust in the government. According to some expert claims, an important percentage of incarcerated adivasis are in jail due to false accusations of being Maoist supporters, for example. Working for one of the conflict parties often also presents one of the few employment opportunities for the local population, since both insurgents and government forces value knowledge about the local conditions. Therefore, adivasis function as tacit supporters, informants, and recruited fighters on both sides of the conflict. ${ }^{6}$

The intensity of the conflict seems to have decreased substantially since 2005 , however. ${ }^{7}$ The insurgents have been losing ground in a number of Indian states, including Bihar and even their stronghold states Jharkhand and Chhattisgarh, while the Maoists seem to have abandoned Andhra Pradesh almost completely. Instead, they appear to be forced to retreat to the Dandakaranya forest area where their headquarters are assumed to be. Better information seems to have been a major factor in this development: While the Maoists accuse the government of turning civilians into police informers and exploiting the information surrendered Maoists have on the organization, the Indian Home Secretary Gopal K. Pillai said in 2010 that the police have become more effective at catching Maoists due to improved information gathering. ${ }^{8}$

\section{The National Rural Employment Guarantee Scheme}

The National Rural Employment Guarantee Scheme (NREGS) is India's most ambitious anti-poverty program and the largest public-works program in the world. Based on the National 
Rural Employment Guarantee Act (NREGA) that was passed in the Indian parliament in August 2005, the scheme provides a legal guarantee of 100 days of public-works employment annually for each rural household at the minimum wage. Households can choose when to apply for employment and are entitled to unemployment allowance if wages are not paid within 15 days after the work was performed. ${ }^{9}$

NREGS was rolled out in three implementation phases: The first 200 districts received the program in February 2006 (Phase 1), followed by 130 districts in April 2007 (Phase 2), and the remaining non-urban districts in April 2008 (Phase 3). Preference was given to underdeveloped districts. Figure 1 shows that there is a large overlap between Maoist activity and poverty among districts: The red districts are all districts that actually received the employment guarantee program in the first phase, whereas the red-white shaded districts are the Phase 1 districts with at least one incident of insurgency-related violence during our study period. In our empirical analysis we will therefore focus on the first implementation phase. Districts affected by Maoist-related violence are also often referred to as red-corridor districts.

We next discuss our data, empirical strategy, and results.

\section{Data}

We use data on Maoist-related incidents that comes from the South Asian Terrorism Portal (SATP), a website maintained by the Institute of Conflict Management in New Delhi. The institute is a nongovernmental organization that provides consultancy services to governments on insurgency-related activities. Their website collates and summarizes news articles, highlighting the date and location of the incident as well as the number of casualties, injuries, and abductions.

For each district in a given month, we construct a measure of the number of casualties and a separate variable that includes the number of injured, captured, and abducted persons. We also enumerate the total number of incidents and the number of "major" incidents as classified by the website. These are our primary variables of interest. As an extension, we also focus on who initiates the attacks: The police, the Maoists, or an ambiguous party in cases reported as "encounters" between the two. Our dataset includes 1,458 Maoist-related incidents, covering about 2,030 fatalities, and 2,545 injuries, abductions, and captures.

The website begins recording the incidents from January 2005, giving us about thirteen months of data before the first phase of NREGS was implemented. Since we focus on Phase 1 implementation, we use data until March 2007 (after which Phase 2 was implemented). This dataset is combined with information on the assignment of districts to implementation

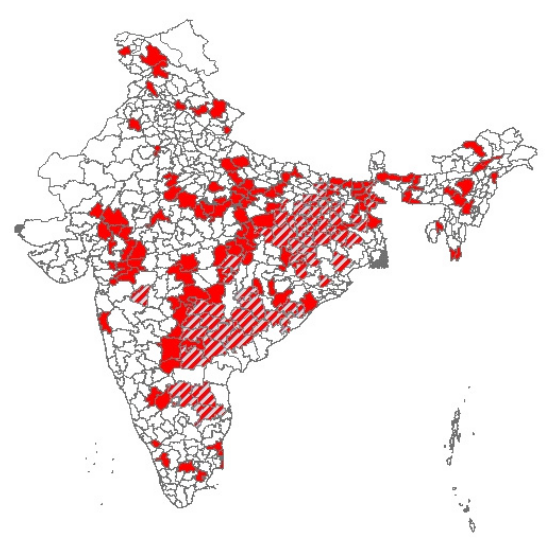

Figure 1: Map of Phase 1 NREGS districts and Maoist-violence affected districts.

phases, which is available from the official NREGS website. ${ }^{10}$ We also collected data on the police force (number of officers, stations, and other measures of police strength) from the Home Ministry of India, which are used as control variables in our regressions.

Using a dataset that relies on news reports has potential drawbacks: Maoist injuries and deaths are difficult to verify, and the police may inflate these numbers or blame Maoists for certain civilian deaths. Some of these issues are alleviated because the police are required to disclose the names and ranks of persons killed to corroborate their reports, and media reports should be less prone to manipulation attempts than administrative sources. In our empirical analysis, these limitations are only a serious concern if the quality of reporting changed systematically after NREGS was implemented in a given district, and we have no reason to believe that this was the case.

\section{Empirical strategy}

The empirical strategy used in this article is a difference-in-difference approach. This strategy makes comparisons on two fronts: First, it compares districts that received NREGS in a given phase with districts that did not. Second, it compares districts before and after NREGS was implemented. Since Phase 1 districts were supposed to receive NREGS in February 2006, our regressions therefore compare incidents of violence in Phase 1 districts before and after this date with other districts (Phase 2 and 3) before and after February 2006.

In order for this to be a valid empirical strategy, two assumptions need to be satisfied: The trends in violence between Phase 1 and non-Phase 1 districts need to be the same 
before NREGS was introduced (although the violence levels can differ between the two groups), and there should be no other programs or policy changes in NREGS districts that were implemented simultaneously with the employment guarantee program. The second assumption holds since to the best of our knowledge the Indian government did not simultaneously start implementing any other program or policy in exactly the same districts that received NREGS.

One possible concern relating to the first assumption is that political manipulation may have led to the inclusion or exclusion of certain districts. If this manipulation led to the inclusion of districts that had an upward trend in violence, for example, then a normal difference-in-difference approach would produce biased results. In the companion paper, we show that this concern does not affect the results reported in this article: We have information on the government algorithm used to assign districts to implementation phases, allowing us to identify districts that should have received NREGS in Phase 1 , and a difference-in-difference specification using this variable instead yields very similar empirical results. The companion paper also uses a different statistical method (a regression-discontinuity design) that does not require this parallel-trend assumption, and the results are again robust to this specification change.

Here, we use the following difference-in-difference regression specification for Phase 1 implementation:

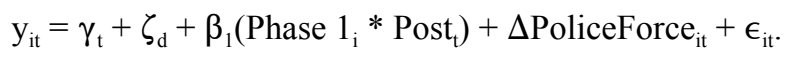

The outcome variables $\left(\mathrm{y}_{\mathrm{it}}\right)$ are casualties, the number of incidents, the number of "major" incidents, the number of injuries, abductions, and captures, and who initiates the attack in district $i$ and month-year $t$. Month-by-year fixed effects $\left(\gamma_{\mathrm{t}}\right)$ control for either seasonal or month-specific spikes in violence and for other time-varying incidents that may affect the entire country. The term $\zeta_{\mathrm{d}}$ reflects district-level fixed effects, which help account for the fact that certain districts may have higher levels of violence that are not associated with NREGS. It also controls for other time-invariant district characteristics like the type of socio-political and economic conditions in a district. As there may have been changes in the police force associated with NREGS implementation, the regression controls for estimated changes in police force characteristics using the Home Ministry data.

The coefficient of interest $\left(\beta_{1}\right)$ is referred to as the difference-in-difference estimator. It is the coefficient on the variable that interacts being in a Phase 1 district (i.e., Phase $1_{i}$ $=1$ for Phase 1 districts, and 0 otherwise), and the post-implementation period (i.e., Post $_{\mathrm{t}}=1$ after February 2006, and 0 otherwise). This coefficient captures the causal impact of receiving NREGS on the incidence of violence in a district. ${ }^{11}$

\section{Results}

Table 1 presents the empirical results. Panel A looks at the main variables of interest (deaths, injuries, incidents), whereas Panel B analyzes who initiated these incidents. Focusing on Panel A, we see that the total number of fatalities increased by 0.19 deaths a month in a district that received NREGS. Since the mean value of deaths in a typical red-corridor district is 0.44 deaths per month, this represents a 43 percent increase in fatalities. The total number of incidents rose by about 0.065 incidents a month in districts that receive NREGS, which corresponds to a 20.6 percent increase in red-corridor districts. This translates into approximately 410 more deaths in about 140 more incidents over the following year. The number of individuals affected by violence in the form of injuries, abductions, or captures also increased, by 0.05 persons per month. All of these effects are statistically significant, whereas the effect of NREGS on the number of major incidents, while positive, is not statistically different from zero.

Panel B provides insight into who initiates these attacks. Once NREGS is implemented in a certain district, police-initiated attacks rise, as do the number of encounters between the police and Maoists. While Maoist-initiated attacks also rise, this increase is not statistically significant.

Overall, these results show that the total number of violence-affected individuals and the number of incidents increase, with the bulk of this effect being driven by police-initiated attacks, and by encounters that take place between police forces and the Maoists usually while the police conduct "combing"-operations in the forests. These patterns are consistent with the idea that the police have better information on Maoist movements after the implementation of NREGS because of larger support by the civilians and therefore more effective tracking of insurgents.

This explanation for the effects of NREGS on Maoist-related violence is also supported by Figure 2, which uses the SATP data to plot the average number of Maoists surrendered or captured by the police in Phase 1 and non-Phase 1 districts over time. The figure highlights the effect of two major events - the passing of the NREGS Act in Parliament, and the implementation of Phase 1. The outcome of interest is the average number of Maoists surrendered or captured in a given month in Phase 1 and non-Phase 1 districts. The figure shows a sharp increase in Phase 1 districts once NREGS is implemented, which starts to decrease after about 8 months of implementation. This indicates the possibility that the police was more successful in catching Maoists right after NREGS 
implementation, and that this may lead to a fall in overall Maoist-related activities in the longer run.

\section{Discussion and conclusion}

The results reported in this article show that the introduction of NREGS, the world's largest public-works program, has led to an increase of Maoist-related violence in the short run: The number of people affected, both in terms of fatalities as well as in terms of injuries, abductions, and police arrests, increased and there was also a larger number of Maoist-related incidents in treatment areas. The measured effects are large in percentage terms, even compared to the red-corridor districts where most of the violence is concentrated. This increase in violence is driven by police-initiated attacks and a larger number of encounters between police forces and the insurgents rather than by Maoist-initiated attacks. The number of Maoists arrested by the police also sharply increases over time.

The most plausible explanation for these effects is that NREGS has helped the police become more successful at gathering information about the movement of the insurgents, which in turn allows them to be more efficient in tracking Maoists rebels. Being the flagship anti-poverty program of the government, NREGS promises substantial economic benefits both in the form of employment and in terms of improvements in local development through the public-works projects. These anticipated benefits, potentially combined with a feeling that NREGS demonstrates the commitment of the government to helping the poor, may have induced civilians in the Maoist-affected areas to increase their support for the government by sharing more information with the police.

In the companion paper, we test some other implications of this citizen-support channel as well as the predictions of alternative theories. One of the main predictions of the information channel is its dynamic pattern: As long as civilians react to the promise of development rather than waiting for these benefits to actually be realized, they should start sharing information with the police immediately, leading to an increase in violence in the short run. Over time, however, a more effective police force should mean that the insurgents are losing ground and therefore lead to a downward trend in violence. We show in the companion paper that this pattern holds
Table 1: Main results and "who initiates" the attacks

Panel A: Main variables

\begin{tabular}{|c|c|c|c|c|}
\hline & Fatalities & $\begin{array}{l}\text { Injuries, } \\
\text { abductions, } \\
\text { captured }\end{array}$ & $\begin{array}{l}\text { Major } \\
\text { incidents }\end{array}$ & $\begin{array}{l}\text { Total } \\
\text { incidents }\end{array}$ \\
\hline NREGS & $\begin{array}{l}0.190 * * * \\
(0.0713)\end{array}$ & $\begin{array}{l}0.0460 \text { *** } \\
(0.0161)\end{array}$ & $\begin{array}{l}0.0194 \\
(0.0126)\end{array}$ & $\begin{array}{l}0.0654 * * \\
(0.0259)\end{array}$ \\
\hline Observations & 12,069 & 12,069 & 12,069 & 12,069 \\
\hline $\begin{array}{l}\text { R-squared } \\
\text { Mean value }\end{array}$ & 0.356 & 0.219 & 0.319 & 0.446 \\
\hline $\begin{array}{l}\text {-all districts } \\
\text { Mean value }\end{array}$ & 0.116 & 0.146 & 0.015 & 0.084 \\
\hline -red corridor & 0.441 & 0.553 & 0.058 & 0.317 \\
\hline
\end{tabular}

Panel B: Who initiates the attacks?

\begin{tabular}{|c|c|c|c|c|}
\hline & $\begin{array}{l}\text { Police } \\
\text { initiated }\end{array}$ & $\begin{array}{l}\text { Maoist } \\
\text { against } \\
\text { police }\end{array}$ & $\begin{array}{l}\text { Maoist } \\
\text { against } \\
\text { civilians }\end{array}$ & Encounters \\
\hline NREGS & $\begin{array}{l}0.0203 * * * \\
(0.00647)\end{array}$ & $\begin{array}{l}0.00648 \\
(0.00488)\end{array}$ & $\begin{array}{l}0.0129 \\
(0.0121)\end{array}$ & $\begin{array}{l}0.0203 * * * \\
(0.00771)\end{array}$ \\
\hline Observations & 12,069 & 12,069 & 12,069 & 12,069 \\
\hline $\begin{array}{l}\text { R-squared } \\
\text { Mean value }\end{array}$ & 0.125 & 0.170 & 0.309 & 0.184 \\
\hline $\begin{array}{l}\text {-all districts } \\
\text { Mean value }\end{array}$ & 0.019 & 0.011 & 0.033 & 0.014 \\
\hline -red corridor & 0.070 & 0.040 & 0.123 & 0.052 \\
\hline
\end{tabular}

Figure 2: Average (over districts) number of Maoists surrendered or captured in a given month.

empirically and that it cannot be explained by the two main alternative theories: Both an increase in the opportunity cost of being a Maoist supporter because of NREGS employment and the increased attractiveness of retaining control over NREGS districts because of the assets created by public-works projects imply very different effects of NREGS over time.

What we cannot completely rule out, however, is the hypothesis that police effectiveness increased through a different mechanism than the citizen-support channel: The 
implementation of NREGS may have put treated districts more in the spotlight, for example, and may therefore have incentivized the police to work harder. In the companion paper, we present some evidence that at least some versions of this explanation do not hold empirically. We show, for example, that the empirical patterns that we find are not driven by increases in the number of police officers and are not consistent with the government pulling police officers out of untreated neighboring districts to focus on the NREGS districts.

Overall, the empirical analyses in this article and the companion paper, combined with the anecdotal evidence that information-gathering is an important characteristic of the conflict, make the citizen-support channel seem like the most plausible explanation. This conclusion suggests that the introduction of NREGS has helped the government fight the insurgents. An important policy implication of the results is that civilians should be seen as a third key player in internal conflicts and should not be ignored in policymaking and research. Anti-poverty programs that demonstrate the government's willingness to improve the economic conditions of the poor, local population in conflict areas may therefore be a potentially valuable tool in a number of other contexts as well.

At the same time, we still know very little about the long-run success of such a strategy. While the citizen-support channel in the short run merely relies on the promise of development, retaining the support of civilians over time may depend crucially on actually keeping this promise and continuing the commitment to the fight against poverty. In the context of ambitious programs like NREGS where there is growing evidence of severe implementation problems in at least some areas of the country, this means that the program may only be successful in improving the relationship between civilians and the government if the implementation quality of NREGS increases.

\section{Notes}

1. Ministry of Home Affairs (2006); Hindustan Times,"Naxalism biggest threat: PM" (13 April 2006).

2. The scheme was renamed to Mahatma Gandhi National Rural Employment Guarantee Scheme (MGNREGS) in 2009.

3. The companion paper, Khanna and Zimmermann (2013), uses a regression discontinuity design that does not require some of the assumptions that we make in this article with regard to the use of a difference-in-difference approach.

4. Cross-country: Collier and Hoeffler (2007). Micro-level: Do and Iyer (2007); Murshed and Gates (2005); Barron, Kaiser, and Pradhan (2004); Humphreys and Weinstein (2008). Adverse economic shocks: Miguel, et al. (2004); Miguel and
Satyanath (2011). Impact of development programs on conflict: Berman, et al. (2011); Crost, et al. (2012); Crost, et al. (forthcoming); Nunn and Qian (2012). Companion paper: Khanna and Zimmermann (2013).

5. Naxalites: The correct way of addressing the insurgents is debated. Mukherji (2012) argues that they should be referred to as Maoists rather than Naxalites since the organizations that grew out of the original Naxalite movement of the 1960s mostly reject the actions of the Communist Party of India (Maoist) $[\mathrm{CPI}(\mathrm{M})]$ that is largely responsible for the violence in recent years. Intensity of conflict: See, e.g., Kujur (2009); Lalwani (2011).

6. Adivasi: a blanket term for a varied set of ethnic and tribal groups thought to constitute the aboriginal population of India. Both sides of the conflict: See, e.g., Bakshi (2009); Mukherji (2012); Lalwani (2011); Sundar (2011).

7. There was a temporary spike in violence in $2009 / 2010$ as a reaction to Operation Green Hunt, a military initiative by the Government of India and some Indian states against the Maoists.

8. Regions, forest areas, headquarters: See, e.g., Mukherji (2012). Home Minister: The summary of a lecture given by Gopal K. Pillai on 10 March 2010 is available at: http://www.idsa.in/event/EPLS/Left-WingExtremisminIndia. A press report from 2007, available on the website www.satp.org, reports: "The CPI-Maoist reportedly issued a press release at Chintapalli village in the Visakhapatnam District, blaming the Police for turning the Girijans (local tribals) into informers by spending huge amounts of money ... [and] that surrendered Maoists are helping the Police, were not leading a normal life and were always with the Police who provided them with all luxuries and used them in combing operations ..."

9. For more details on the scheme see, e.g., Dey, et al. (2006); Government of India (2009); Ministry of Rural Development (2010). Some papers have analyzed the economic effects of the program: See, e.g., Berg, et al. (2012), Imbert and Papp (2013); Zimmermann (2013).

10. See www.nrega.nic.in.

11. Standard errors are clustered at the district level, which allows observations in the same district to be correlated and therefore produces more conservative estimates than standard errors calculated at the incident level.

\section{References}

Bakshi, G.D. 2009. "Left Wing Extremism in India: Context, Implications and Response Options." Manekshaw Paper No. 9. http:/www.claws.in/administrator/uploaded_files/ 1249630947Manekshaw\%20Paper\%20\%209\%20\%202009 .pdf.

Barron, P., K. Kaiser, and M. Pradhan. 2004. "Local Conflict in Indonesia: Measuring Incidence and Identifying Patterns." World Bank Policy Research Working Paper, 3384. http://elibrary.worldbank.org/doi/book/10.1596/ 
1813-9450-3384

Berg, E., S. Bhattacharyya, R. Durgam, and M. Ramachandra. 2012. "Can Rural Public Works Affect Agricultural Wages? Evidence from India." Centre for the Study of African Economies, Oxford University. Working Paper WPS/2012-05. http://www.csae.ox.ac.uk/workingpapers/ pdfs/csae-wps-2012-05.pdf.

Berman, E., J.N. Shapiro, and J.H. Felter. 2011. "Can Hearts and Minds Be Bought? The Economics of Counterinsurgency in Iraq." Journal of Political Economy. Vol. 119, No. 4, pp. 766-819. http://dx.doi.org/10.1086/661983

Collier, P. and A. Hoeffler. 2007. "Civil War," in K. Hartley and T. Sandler, eds. Handbook of Defense Economics. Vol. 1. Amsterdam: Elsevier North Holland.

Do, Q.-T. and I. Lakshmi. 2007. "Poverty, Social Divisions and Conflict in Nepal." Unpublished working paper. Harvard Business School. http://www.hbs.edu/faculty/ Publication\%20Files/07-065.pdf.

Crost, B., J. Felter, and P. Johnston. 2012. "Conditional Cash Transfers and Civil Conflict: Experimental Evidence from the Philippines." Mimeo. http://econ.ucdenver.edu/bcrost/ research $/ \mathrm{CCT} \% 20$ and $\% 20$ conflict.pdf.

Crost, B., J. Felter, and P. Johnston. Forthcoming (forthcoming). "Aid Under Fire: Development Projects and Civil Conflict." American Economic Review. http://patrickjohnston.info/materials/AUF.pdf.

Dey, N., J. Dreze, and R. Khera. 2006. Employment Guarantee Act: A Primer. Delhi: National Book Trust, India.

Government of India. 2009. "The National Rural Employment Guarantee Act.” http://nrega.nic.in/Nrega_guidelines.pdf.

Humphreys, M. and J.M. Weinstein. 2008. "Who Fights? The Determinants of Participation in Civil War." American Journal of Political Science. Vol. 52, No., 2, pp. 436-455.

Imbert, C. and J. Papp. 2013. "Labor Market Effects of Social Programs: Evidence of India's Employment Guarantee." Centre for the Study of African Economies. Oxford University. Working Paper WPS/2013-03. http:/www.csae.ox.ac.uk/workingpapers/pdfs/csae-wps2013-03.pdf.

Kujur, R. 2009. "Naxal Conflict in 2008: An Assessment." Institute for Peace and Conflict Studies. Issue Brief. New Delhi.

Khanna, G. and L. Zimmermann. 2013. "Guns and Butter? Fighting Violence with the Promise of Development." Mimeo. http://www-personal.umich.edu/ lvzimmer/ Khanna_Zimmermann guns_and butter.pdf.

Lalwani, S. 2011. "India's Approach to Counterinsurgency and the Naxalite Problem." (Combating Terrorism Center) CTC Sentinel. Vol. 4, No. 10, pp. 5-9. http://www.ctc.usma.edu/ posts/india $\%$ E2\%80\%99s-approach-tocounterinsurgency-and-the-naxalite-problem.

Miguel, E., S. Satyanath, and E. Sergenti. 2004. "Economic Shocks and Civil Conflict: An Instrumental Variables Approach." Journal of Political Economy. Vol. 112, No. 4, pp. $725-753$. http://dx.doi.org/10.1086/421174

Miguel, E. and S. Satyanath. 2011. "Re-examining Economic Shocks and Civil Conflict." American Economic Journal: Applied Economics. Vol. 3, No. 4, pp. 228-232.

Ministry of Home Affairs. Government of India. 2006. “Annual Report 2006-2007.” http://mha.nic.in/hindi/sites/ upload_files/mhahindi/files/pdf/ar0607-Eng.pdf.

Ministry of Rural Development. Department of Rural Development. Government of India. 2010. "Mahatma Gandhi National Rural Employment Guarantee Act 2005Report to the People 2nd Feb. 2006-2nd Feb. 2010." http://nrega.nic.in/circular/Report_to_the_people.pdf.

Mukherji, N. 2012. The Maoists in India: Tribals under Siege. London: Pluto Press.

Murshed, S.M. and S. Gates. 2005. "Spatial-Horizontal Inequality and the Maoist Insurgency in Nepal." Review of Development Economics. Vol. 9, No. 1, pp. 121-134. http://dx.doi.org/10.1111/j.1467-9361.2005.00267.x

Nunn, N. and N. Qian. 2012. "Aiding Conflict: The Impact of U.S. Food Aid on Civil War." NBER Working Paper No. 17794. National Bureau of Economic Research. Cambridge, MA. http://www.nber.org/papers/w17794.pdf.

Sundar, N. 2011. "At War with Oneself: Constructing Naxalism as India's Biggest Security Threat," in M. Kugelman, ed. India's Contemporary Security Challenges. Princeton, NJ: Woodrow Wilson International Center for Scholars Asia Program.

Zimmermann, L. 2013. "Why Guarantee Employment? Evidence from a Large Indian Public-Works Program." Mimeo. http://www-personal.umich.edu/ lvzimmer/ Zimmermann_NREGS_current_draft.pdf. 